\section{Clients' willingness to pay for immunization services in the urban and rural primary health centers of Enugu state, Nigeria}

\author{
Edmund Ndudi Ossai, ${ }^{1}$ \\ Akinola Ayoola Fatiregun ${ }^{2}$ \\ 'Department of Community Medicine, \\ College of Health Sciences, Ebonyi State \\ University, Abakaliki; ${ }^{2}$ World Health \\ Organization, Akure, Ondo State, Nigeria
}

\begin{abstract}
Our study aims at determining the pattern of willingness of clients to pay for childhood immunization services in urban and rural primary health centers of Enugu state, Nigeria. Using a cross-sectional design, 800 clients who presented with their children/wards to receive childhood immunization services were selected at the primary health center in rural and urban local government areas of the state. The mean age was $28.9 \pm 4.5$ and $26.7 \pm 5.1$ years in the urban and rural areas respectively. About $54.5 \%$ of clients in the urban and $55.3 \%$ in the rural area were willing to pay for immunization services. The clients willingness to pay was influenced by: non satisfaction with immunization services, $(\mathrm{OR}=0.3,95 \% \mathrm{CI}$ : 0.2 $0.5)$, younger age, $(\mathrm{OR}=1.4,95 \% \mathrm{CI}$ : $1.0-2.0)$ marital status (OR=2.8, 95\% CI: $1.2-6.5)$, proximity to health centers $(\mathrm{OR}=0.6,95 \% \mathrm{CI}$ : 0.4 0.8 ), and delivering in a private health facility $(\mathrm{OR}=0.4,95 \% \mathrm{CI}: 0.1-0.9)$. The study suggests that the economic value that clients give to immunization services was similar in the rural and urban areas, and this could be increased by improving the level of clients' satisfaction for the services among others.
\end{abstract}

\section{Introduction}

Immunization remains one of the pillars of global public health, and with the additional incentive that its services are free, ${ }^{1}$ the concern on why universal coverage hasn't been reached still remains a problem. For example, in Nigeria, the immunization coverage is very low as only $23 \%$ of children aged $12-23$ months are fully immunized, and $29 \%$ of the children do not receive any vaccination. ${ }^{2}$ It has been noted that children are not fully immunized in Nigeria due to the non-availability of vaccines, ${ }^{3}$ place of immunization being too far, ${ }^{4}$ unaware of the need of immunization, fear of side effects, and mother being too busy. ${ }^{5}$ Some of these reasons point to compet- ing priorities by mothers and caregivers and this could be attributed to the poor economic value attached to immunization and its services. Studies on willingness to pay are however useful in determining the economic value individuals attach to medical services. In Nigeria also, the majority of the populace reside in the rural areas, where the immunization coverage is lower, and the inhabitants are poorer. ${ }^{2}$ This study was therefore conducted to determine the willingness of clients to pay for childhood immunization services and explore factors that may affect such willingness in the urban and rural primary health centers in Enugu state Nigeria.

\section{Materials and Methods}

\section{Setting}

Enugu state operates the District Health System with seven district hospitals, (namely Awgu, Udi, Enugu Ezike, Agbani, Nsukka, Isi Uzo and Enugu Metropolis), 440 primary health care facilities, 40 cottage hospitals, 2 specialist hospitals, 2 teaching hospitals and 384 mission/private hospitals and clinics. ${ }^{1}$ All the primary health centers in Enugu state offer free immunization services. ${ }^{1}$

\section{Study design}

A cross sectional analytical study design was used. Clients' willingness to pay for immunization services in the urban and rural primary health centers of Enugu state was compared.

\section{Study participants}

The study population consisted of clients who presented with their children/wards for immunization services at the primary health centers selected for the study.

\section{Sample size determination}

A minimum sample size of 400 clients per group was estimated to detect a $2 \%$ difference in willingness to pay for immunization among urban and rural clients at a type 1 error $(\alpha)$ of 0.05 , (in a two sided test), and a power of 0.8 .

\section{Sampling technique}

A three-stage sampling technique was used. In the first stage, a simple random sampling technique by balloting was used to select three local government areas each from the urban and rural areas of the state. In the second stage, three health centers each from the six local government areas were randomly selected by balloting. In the third stage, we used a systematic random sampling technique to
Correspondence: Akinola Ayoola Fatiregun, World Health Organization, Field Office, United Nations House, Plot 617/618, Central Area District, PMB 2861, Abuja, Nigeria.

Tel.: 08033720966

E-mail: fatireguna@who.int, fatireguna@ gmail.com.

Key words: Willingness to pay; immunization; urban and rural; Enugu State Nigeria.

Acknowledgements: the authors recognized the valuable contribution of Adewale Moses Adejugbagbe for assisting with the preparation of the manuscript.

Contributions: This work was carried out in collaboration between both authors. Author AAF conceptualized the study, while both were involved in the design. Author ENO did literature search and supervised the collection of the data. All authors were involved in data analysis and interpretation of results. Author ENO wrote the initial draft , which was revised by author AAF.

Conflict of interest: the authors declare no potential conflict of interest.

Received for publication: 3 May 2015 .

Revision received: 1 March 2016.

Accepted for publication: 9 March 2016.

This work is licensed under a Creative Commons Attribution NonCommercial 3.0 License (CC BYNC 3.0).

CC Copyright E.N. Ossai and A.A. Fatiregun, 2015 Licensee PAGEPress, Italy

Journal of Public Health in Africa 2015; 6:480 doi:10.4081/jphia.2015.480

select the clients as they presented in the immunization/infants welfare clinic on each day of data collection. The average of the last six months daily attendance at the health centers for immunization services was used to determine the target population size, and dividing this with the estimated sample size of 400 , we obtained the sampling interval of five in the urban area, and four in the rural. The index client was selected among the first five clients in the urban, and first four clients in the rural by simple random sampling method through balloting using the health facility register of clients on each day of data collection. In-order to ensure that a client was not selected twice, there was a register for all clients that had been included in the study and this was cross checked by the research assistants before a new client was included.

\section{Data collection}

The study instrument for data collection was an adapted interviewer administered questionnaire. Apart from the socio-demographic data, 
the questionnaire in addition had variables on client satisfaction with immunization services received, willingness of the clients to pay for the services and the reasons for such disposition. For those who expressed willingness to pay, data was also sought on how much they were willing to pay.

\section{Data analysis}

The analysis was done using SPSS statistical software, version 20. Frequency tables and cross-tabulations were generated, and level of significance was determined at a $\mathrm{P}$ value of less than 0.05 . We compared the socio-demographic characteristics of the clients in the urban and rural. Clients satisfaction with immunization services, denoted as true satisfaction, was a composite index which was assessed by the proportion of clients who reported being satisfied with immunization services received on the day of data collection, and were also willing to use the health center again for immunization services, in addition to being willing to recommend the health center to others for same services. The outcome measure was the willingness of the clients to pay for the services. Comparisons of independent and the outcome variables were made between the rural and urban settings using chi-square test. Multivariate analysis using binary logistic regression was used to determine factors associated with the willingness of clients to pay. Variables that had a $\mathrm{P}<0.20$ on bivariate analysis were entered into the logistic regression model to determine the predictors of the willingness of the clients to pay for immunization services. Results were reported using odds ratio, confidence interval at $95 \%$ and level of significance was set at $\mathrm{P}<0.05$. Ethical approval for the study was obtained from the Research and Ethics Committee of the University of Nigeria Teaching Hospital, Ituku Ozalla, Enugu.

\section{Results}

Tables 1 and 2 show the socio-demographic characteristics of the clients. The mean age of the clients in the urban areas $(28.9 \pm 4.5$ years $)$ was significantly higher than that in the rural areas $(26.7 \pm 5.1$ years $)$.

Table 3, shows clients willingness to pay for immunization services in the urban and rural primary health centers. Comparable proportions of clients in the urban (54.5\%) and rural (55.3\%) were willing to pay for immunization services.

Tables 4 and 5 respectively show bivariate and multivariate outputs for factors that were assessed to have potential influences on client's willingness to pay for immunization services. True satisfaction with immunization services received $(\mathrm{P}<0.001)$, the marital status $(\mathrm{P}<0.001)$, the educational status of the index child's father $(\mathrm{P}=0.011)$ and proximity to the health centers $(\mathrm{P}=0.022)$ were the main factors that affected the willingness to pay for immunization services on bivariate analysis. On the other hand, multivariate logistic regression revealed that clients who were not truly satisfied with immunization services $(\mathrm{OR}=0.28,95 \% \mathrm{CI}$ : 0.16-0.49), married, (OR=2.78, 95\%CI: 1.20 $6.46)$, of younger age group ( $<31$ years), (OR=1.43, 95\%CI: 1.03-1.98), close to the health centers, $(\mathrm{OR}=0.60,95 \% \mathrm{CI}$ : $0.43-0.83)$, and who delivered their children in private health facilities (OR=0.36, 95\%CI: 0.13-0.96) were significant predictors of the willingness to pay for immunization services (Table 5).

\section{Discussion}

Finding of our study showed that similar

proportions of clients in the two study areas, (urban 54.5\% and rural 55.3\%) were willing to pay for immunization services, suggesting that economic values attached to immunization services are equal in both areas. The proportions of those willing to pay for immunization services in this study were however lower than that in a study in rural districts of Bangladesh where $86 \%$ of the respondents were willing to pay for immunization services and in another study in urban Bangladesh, ${ }^{6}$ where $93 \%$ of the respondents were willing to pay nominal fees for immunization services. ${ }^{7}$ Socio-cultural differences as well as economic considerations may explain the differences.

The majority of clients in the two study areas were disposed to paying for immunization services because they were concerned about saving the lives of their children. A minor proportion, $11.9 \%$ in the urban and $14.5 \%$ in the rural area, were willing to pay for immunization services so that the money realized could be used to purchase vaccine equipment and cards. This might be a conscious

Table 1. Socio-demographic characteristics of clients of immunization services in the urban (total: 400) and rural (total: 400) primary health centers of Enugu state, August 2013.

\begin{tabular}{|c|c|c|c|}
\hline Variable & Urban, N. (\%) & Rural, N. (\%) & P-value \\
\hline Age of clients & & & $<0.001^{*}$ \\
\hline Mean $\pm S D$, years & $28.9 \pm 4.5$ & $26.7 \pm 5.1$ & \\
\hline $\begin{array}{l}\text { Age of index child } \\
\text { Mean } \pm \text { SD, months }\end{array}$ & $3.9 \pm 3.3$ & $3.7 \pm 2.9$ & 0.435 \\
\hline $\begin{array}{l}\text { Relationship of client to child } \\
\text { Mother } \\
\text { Father } \\
\text { Female guardian }\end{array}$ & $\begin{array}{l}390(97.5) \\
5(1.3) \\
5(1.3)\end{array}$ & $\begin{array}{l}392(98.0) \\
6(1.5) \\
2(0.5)\end{array}$ & 0.501 \\
\hline $\begin{array}{l}\text { Position of index child } \\
\qquad \begin{array}{l}1 \\
2-4 \\
\geq 5\end{array}\end{array}$ & $\begin{array}{c}109(27.3) \\
257(64.3) \\
34(8.5)\end{array}$ & $\begin{array}{l}103(25.8) \\
248(62.0) \\
49(12.3)\end{array}$ & 0.219 \\
\hline $\begin{array}{l}\text { Marital status } \\
\text { Married } \\
\text { Never married } \\
\text { Separated/divorced/widowed }\end{array}$ & $\begin{array}{c}390(97.5) \\
10(2.5) \\
0(0)\end{array}$ & $\begin{array}{l}371(92.8) \\
24(6.0) \\
5(0.6)\end{array}$ & $0.001^{\circ}$ \\
\hline $\begin{array}{l}\text { Religion } \\
\text { Christian } \\
\text { Others }\end{array}$ & $\begin{array}{l}399(99.8) \\
1(0.2)\end{array}$ & $\begin{array}{l}393(98.3) \\
7(1.8)\end{array}$ & 0.095 \\
\hline $\begin{array}{l}\text { Ethnic group } \\
\text { Igbo } \\
\text { Others }\end{array}$ & $\begin{array}{l}391(97.8) \\
9(2.3)\end{array}$ & $\begin{array}{l}394(98.5) \\
6(1.5)\end{array}$ & 0.434 \\
\hline $\begin{array}{l}\text { Socio-economic status } \\
\text { Least poor } \\
\text { The poor } \\
\text { Very poor } \\
\text { Poorest }\end{array}$ & $\begin{array}{l}157(39.3) \\
121(30.3) \\
86(21.5) \\
36(9.0)\end{array}$ & $\begin{array}{l}45(11.3) \\
84(21.0) \\
107(26.8) \\
164(41.0)\end{array}$ & $<0.001$ \\
\hline $\begin{array}{l}\text { Cost of travel to reach the health center (naira) } \\
\text { Mean } \pm \text { SD }\end{array}$ & $86.5 \pm 57.7$ & $69.6 \pm 31.7$ & $<0.001^{*}$ \\
\hline $\begin{array}{l}\text { Estimated distance to health center } \\
<1 \mathrm{~km} \text { from home } \\
1-5 \mathrm{~km} \text { from home } \\
>5 \mathrm{~km} \text { from home }\end{array}$ & $\begin{array}{l}251(62.8) \\
108(27.1) \\
41(10.5)\end{array}$ & $\begin{array}{l}278(69.5) \\
118(29.5) \\
4(1.0)\end{array}$ & $<0.001$ \\
\hline
\end{tabular}

*Student t-test; 'likelihood ratio; \#Islam and traditional African religion; §Yoruba, Hausa and the minority tribes. 
effort on the part of the clients at ensuring the sustainability of the immunization programs. The least proportion of those who were willing to pay for immunization services viewed such payments as a way of motivating the health workers. This reveals also that this minor proportion of clients do appreciate the good works of the health workers in the discharge of their duties especially in the area of immunization and its services.

The majority of the clients who were unwilling to pay for immunization services did so because they perceived such services as the responsibility of government. This is similar to the finding in the study in the rural districts of Bangladesh where such services were also regarded as the prime function of government by those who were unwilling to pay for such services. ${ }^{6}$ The remaining proportion of those who were unwilling to pay had a slightly different viewpoint, they were of the opinion that immunization services have always been free, aware also that it may have always been provided for, by the government. Perhaps, they were wondering also, why such important service as immunization could be made to attract charges now that they are in their reproductive age period. Our study suggests that clients who were not satisfied with immunization services received were less willing to pay for services. This is closely related to a finding from a study on community satisfaction with the quality of maternal and child health services in Southeast Nigeria in which it was found that people were willing to pay for primary health care services if there were quality improvements. ${ }^{8}$ This finding is in line with the viewpoints of economists, who have long pointed out that consumers of health care are in favor of high quality care even if that will attract increased charges. ${ }^{9}$ The World Bank has also been in support of measures that will ensure that clients of health care services are satisfied with services received as it has encouraged developing countries to ensure that their health services are client oriented. ${ }^{10}$ Furthermore, the relevance of clients satisfaction with health care services is also buttressed by the finding that it determines adherence to treatment and also follow up measures as these will eventually lead to positive health outcomes. ${ }^{11}$

The higher proportion of clients that were in their younger age group and more willing to pay for immunization services could be explained by the fact that this group may be concerned about the welfare of their children than the consideration that immunization is the responsibility of the government. Those who were married were also found to be more willing to pay for immunization services and this could be attributed to the family support from partners which may be missing from clients who were single. The finding that clients who live far from the health centers were more willing to pay for immunization services may be that by living far, they may likely pay more as transport fares to the health centers and hence are more motivated to obtaining the service. This may be at variance with the finding that long distance walking to the health centers was one of the factors responsible for the partial immunization of children. ${ }^{4}$

Clients who delivered their babies at private health facilities were less willing to pay for immunization services when compared to those who delivered their babies at home. The proportions of clients that delivered at home are very low compared to those that delivered in the private health facility and this may have influenced the comparison. In addition, almost

Table 2. Socio-demographic characteristics of parents of index child brought for immunization services in the urban (total 400) and rural (total 400) primary health centers of Enugu state, August 2013.

\begin{tabular}{lccc}
\hline Variable & Urban, N. (\%) & Rural, N. (\%) & P-value \\
Education of mother of index child & & & \multirow{2}{*}{0.001} \\
$\quad$ No formal education & $1(0.3)$ & $3(0.8)$ & \\
Primary education & $30(7.5)$ & $49(12.3)$ & \\
Secondary education & $255(63.8)$ & $301(75.3)$ & \\
Post secondary education & $114(28.5)$ & $47(11.8)$ & \\
Occupation of mother & & & 0.015 \\
Self employed & $211(52.8)$ & $238(59.5)$ & \\
Unemployed/housewife & $130(32.5)$ & $128(32.0)$ & \\
Salaried employment & $59(14.8)$ & $34(8.5)$ & \\
\hline Education of father of index child & & & $<0.001$ \\
No formal education & $2(0.5)$ & $18(4.9)$ & \\
Primary education & $31(7.9)$ & $47(12.7)$ & \\
Secondary education & $223(57.2)$ & $241(65.0)$ & \\
Post secondary education & $134(34.4)$ & $65(17.5)$ & \\
Occupation of father & & & 0.001 \\
Self employed & $269(69.0)$ & $298(80.3)$ & \\
Salaried employment & $116(29.7)$ & $69(18.6)$ & \\
Unemployed & $5(1.3)$ & $4(1.1)$ & \\
\hline
\end{tabular}

Table 3. Clients willingness to pay for immunization services in the urban (total 400) and rural (total 400) primary health centers of Enugu state, August 2013.

\begin{tabular}{lcc}
\hline Variable & Urban, N. (\%) & Rural, N. (\%) \\
Willing to pay for immunization services & & $221(55.3)$ \\
Yes & $218(54.5)$ & $179(44.8)$ \\
No & $182(45.5)$ & $176(79.6)$ \\
Reason to agree to pay for immunization services & $184(84.4)$ & $32(14.5)$ \\
Save the child life & $28(12.8)$ & $13(5.9)$ \\
Purchase vaccine equipment/card & $6(2.8)$ & $109(60.9)$ \\
Motivate the health workers & & $70(39.1)$ \\
\hline Reason not willing to pay for immunization services & $149(81.9)$ & 0.223 \\
Government responsibility & $33(18.1)$ & $219.9 \pm 215.6$ \\
Has always been free & $339.7 \pm 498.1$ & 30 \\
Amount willing to pay on the average for each vaccination (naira) & 50 & 1000 \\
Mean (SD) & 6000 & 175 \\
Minimum & 200 & $0.002 *$ \\
Maximum & & $<0.001$ \\
Median & &
\end{tabular}


Table 4. Bivariate analysis of factors affecting client's willingness to pay for immunization services in the study area, August 2013.

\begin{tabular}{|c|c|c|c|}
\hline Variable & Willing to pay, N (\%) & Not willing to pay, N (\%) & P value \\
\hline $\begin{array}{l}\text { True satisfaction with immunization services } \\
\text { Satisfied } \\
\text { Not satisfied }\end{array}$ & $\begin{array}{l}417(58.3) \\
22(25.9)\end{array}$ & $\begin{array}{c}298(41.7) \\
63(74.1)\end{array}$ & $<0.001$ \\
\hline $\begin{array}{l}\text { Age category } \\
\quad<30 \text { years } \\
\geq 30 \text { years } \\
\end{array}$ & $\begin{array}{l}286(56.7) \\
153(51.7)\end{array}$ & $\begin{array}{l}218(43.3) \\
143(48.3)\end{array}$ & 0.165 \\
\hline $\begin{array}{l}\text { No of living children } \\
\quad \leq 2 \\
\geq 2\end{array}$ & $\begin{array}{l}229(52.8) \\
210(57.4)\end{array}$ & $\begin{array}{l}205(47.2) \\
156(42.6)\end{array}$ & 0.192 \\
\hline $\begin{array}{l}\text { Marital status } \\
\quad \text { Married } \\
\text { Single } \\
\end{array}$ & $\begin{array}{c}430(56.5) \\
9(23.1)\end{array}$ & $\begin{array}{c}331(43.5) \\
30(76.9)\end{array}$ & $<0.001$ \\
\hline $\begin{array}{l}\text { Ethnic group } \\
\text { Igbo } \\
\text { Others }\end{array}$ & $\begin{array}{c}437(55.7) \\
2(13.3)\end{array}$ & $\begin{array}{c}348(44.3) \\
13(86.7)\end{array}$ & \\
\hline $\begin{array}{l}\text { Education of mother } \\
\text { Primary education and below } \\
\text { Secondary education and above }\end{array}$ & $\begin{array}{c}52(62.7) \\
387(54.0)\end{array}$ & $\begin{array}{c}31(37.3) \\
330(46.0)\end{array}$ & 0.133 \\
\hline $\begin{array}{l}\text { Distance from home to health center (estimated) } \\
\quad \leq 1 \text { kilometer } \\
\quad>1 \text { kilometer }\end{array}$ & $\begin{array}{l}275(52.0) \\
164(60.5)\end{array}$ & $\begin{array}{l}254(48.0) \\
107(39.5)\end{array}$ & 0.022 \\
\hline $\begin{array}{l}\text { Place of delivery of child } \\
\text { Private health facility } \\
\text { Public health facility } \\
\text { Traditional birth attendant } \\
\text { Home }\end{array}$ & $\begin{array}{l}207(51.8) \\
176(56.1) \\
37(61.7) \\
19(73.1)\end{array}$ & $\begin{array}{l}193(48.3) \\
138(43.9) \\
23(38.3) \\
7(26.9)\end{array}$ & 0.096 \\
\hline $\begin{array}{l}\text { Relationship of client to child } \\
\text { Mother } \\
\text { Others } \\
\end{array}$ & $\begin{array}{c}429(55.4) \\
10(38.5)\end{array}$ & $\begin{array}{c}345(44.6) \\
16(61.5)\end{array}$ & 0.087 \\
\hline
\end{tabular}

*Fisher's exact test

Table 5. Multivariate analysis of factors affecting clients' willingness to pay for immunization services in the urban and rural primary health centers of Enugu state, August 2013.

\begin{tabular}{|c|c|c|c|c|}
\hline \multirow[t]{2}{*}{ Variable } & \multirow[t]{2}{*}{ Odds ratio } & \multirow[t]{2}{*}{ P value } & \multicolumn{2}{|c|}{$95 \%$ CI for OR } \\
\hline & & & Lower & Upper \\
\hline \multicolumn{5}{|c|}{ True satisfaction with immunization services } \\
\hline No & 0.28 & $<0.001$ & 0.16 & 0.49 \\
\hline Yes & 1 & - & - & - \\
\hline \multicolumn{5}{|l|}{ Age category } \\
\hline$<30$ years & 1.43 & 0.033 & 1.03 & 1.98 \\
\hline$\geq 30$ years & 1 & - & - & - \\
\hline \multicolumn{5}{|l|}{ No of living children } \\
\hline$\leq 2$ & 0.79 & 0.156 & 0.57 & 1.09 \\
\hline$>2$ & 1 & - & - & - \\
\hline \multicolumn{5}{|l|}{ Marital status } \\
\hline Married & 2.78 & 0.017 & 1.20 & 6.46 \\
\hline Single & 1 & - & - & - \\
\hline \multicolumn{5}{|l|}{ Education of mother } \\
\hline Primary education and below & 1.52 & 0.103 & 0.92 & 2.31 \\
\hline Secondary education and above & 1 & - & - & - \\
\hline \multicolumn{5}{|c|}{ Distance from home to health center (estimated) } \\
\hline$\leq 1 \mathrm{~km}$ & 0.60 & 0.002 & 0.43 & 0.83 \\
\hline$>1 \mathrm{~km}$ & 1 & - & - & - \\
\hline \multicolumn{5}{|l|}{ Place of delivery } \\
\hline Private health facility & 0.36 & 0.042 & 0.13 & 0.96 \\
\hline Public health facility & 0.42 & 0.084 & 0.15 & 1.12 \\
\hline Traditional birth attendant & 0.56 & 0.312 & 0.19 & 1.72 \\
\hline Home & 1 & - & - & - \\
\hline \multicolumn{5}{|l|}{ Relationship of client to child } \\
\hline Mother & 3.26 & 0.052 & 0.99 & 10.72 \\
\hline Others & 1 & - & - & - \\
\hline
\end{tabular}


equal proportions of those that delivered at the private facility were willing and not willing to pay. An earlier study observed that private health facilities do charge meager fees for immunization services as against none from the public health facilities, ${ }^{10}$ and these fees in some areas act as barriers to assessing vaccination services. ${ }^{11}$ This may have influenced the clients who delivered in private health facilities to see immunization services as the responsibility of government hence not willing to pay for such services.

\section{Conclusions}

The study suggests that the economic value client attached to immunization services was similar in the rural and urban areas. Client satisfaction was one factor found that is amenable to modification by the health workers among others. Hence, the economic values attached to immunization services could be increased by improving the level of clients' satisfaction for the services.

\section{References}

1. Enugu State Ministry of Health. Policy brief on free maternal and child health care services in Enugu State. Enugu: Ministry of Health Nigeria; 2007.

2. National Population Commission. Nigeria, demographic and health survey, 2003. Available form: http://www.dhsprogram. com/pubs/pdf/FR148/FR148.pdf

3. Fatiregun AA, Okoro A0. Maternal determinants of complete child immunisation among children aged 12-23 months in a southern district of Nigeria. Vaccine 2012;30:730-6.

4. Abdulraheem, IS, Onajole AT, Jimoh AAG, Oladipo AR. Reasons for incomplete vaccination and factors for missed opportunities among rural Nigerian children. J Public Health Epidemiol 2011;3:194-203.

5. No authors listed. National standards for immunisation coverage assessment: recommendations from the Canadian Immunisation Registry Network. Can Commun Dis Rep 2005;31:93-7.

6. Hossain A, Routh S. Charging fees for EPI Services: who are unwilling to pay? Oral presentation. 9th annual scientific conference, health systems research; Meeting the needs of populations in transition.
Inter Center for Diarrheal Disease Research, Bangladesh 2000.

7. Quayyum Z, Thwin AA, Baqui AH, Mazumder MA. Willingness to pay for MCH-FP services of NGOs in urban Bangledesh. Urban reproductive health publications 1997. Available from: www.urbanreproductivehealth.org/willingness-pay-fp-services-n. Accessed 15 September 2013.

8. Uzochukwu BS, Onwujekwe OE, Akpala CO. Community satisfaction with the quality of maternal and child health services in southeast Nigeria. East Afr Med J 2004;81:293-9.

9. Gibson L, Alilio M, Heggenhougen K. Community satisfaction with primary health care services, an evaluation undertaken in the Morogoro region of Tanzania. Soc Sci Med 1994;39:767-80.

10. Oyerinde 00. National programme on immunisation patronage in selected local government areas of Oyo state. Available from: www.unilorin.edu.ng/journals/education. Accessed: 14 December 2013

11. Patro BK, Kumar RK, Goswani A, et al. Community perception and client satisfaction about primary health care services in an urban resettlement colony of New Delhi. Indian J Community Med 2008;33: 250-4. 